\title{
Evaluation of Nutritional and Phytochemical Compositions of Two bitter Leaf (Vernonia amygdalina) Accessions in Nigeria
}

\author{
Okolie, Henry, Ndukwe, Okorie, Obidiebube, Eucharia, Obasi, Chiamaka, Enwerem, Juliet \\ Department of Crop Science and Horticulture, Faculty of Agriculture, Nnamdi Azikiwe University,Awka Nigeria
}

\begin{abstract}
A comparative analysis was done at the Food Profiling Biotechnology Laboratory, National Root Crops Research Institute (NRCRI) Umudike, Umuahia to investigate the proximate, minerals, vitamins and phytochemical compositions of Upland and Riverine accessions of bitter leaf (Vernonia amygdalina). Riverine accession contained more Ash $(9.45 \mathrm{mg} / 100 \mathrm{~g})$ while Upland accession contained more crude fiber $\quad(4.17 \%)$,fat $(2.44 \%)$,carbohydrate $(40.54 \mathrm{mg} / 100 \mathrm{mg})$ and energy value $(288 \mathrm{k} / \mathrm{cal})$. The presence of more ash in Riverine bitter leaf is a confirmation of the presence of more mineral elements. sodium $(180.36 \mathrm{mg} / 100 \mathrm{~g})$, magnesium $(162.54 \mathrm{mg} / 100 \mathrm{~g})$, phosphorus(27.8mg/100g), potassium( $949.35 \mathrm{mg} / 100 \mathrm{mg})$, iron $(1.13 \mathrm{mg} / 100 \mathrm{~g})$ and zinc $(0.48 \mathrm{mg} / 100 \mathrm{~g})$. This makes it a very good source of minerals especially as it can be taken raw. The results showed that Riverine accession contained more Vitamin B1 $(0.16 \mathrm{mg} / 100 \mathrm{~g})$ and Vitamin E $(0.32 \mathrm{mg} / 100 \mathrm{~g})$. While the upland accession contained more of Vitamin B2 $(0.22 \mathrm{mg} / 100 \mathrm{~g})$ and VitaminB3 $(0.15 \mathrm{mg} / 100 \mathrm{mg})$. Upland accession contained more Tannins $(0.75 \%)$, Phytate $(\mathbf{1 2 4 . 1 3} \mathrm{mg} / \mathbf{1 0 0 g})$, Steriods $(0.002 \%)$ and Oxalate $(1.48 \mathrm{mg} / \mathbf{1 0 0 g})$,Cyanogenic glycosides (44.77 $\mathrm{mg} / \mathbf{1 0 0 g}$ ), Anthraquinone (0.06\%) than Riverine Upland accession which contained more Saponin $(\mathbf{0 . 2 1} \%)$. Total Phenols, Flavonoids and Alkaloids were not different. Correlation analysis between phytochemical and proximate components showed that the phytochemical components correlated positively at 0.01 level of significance among themselves and with the proximate components except for saponin, anthraquinone and steroids.
\end{abstract}

Keywords: Vernonia amygdalina; Phytochemicals; Proximate, accession, correlation.

\section{INTRODUCTION.}

$\mathrm{V}$ ernonia amygdalina is a perennial shrub from Asteraceae family and also commonly called 'Bitter Leaf' because of the bitter taste of its leaves. Not only called bitter leaf, this plant also has a lot of other local names in different languages of the different regions of the Nigeria such as; 'Ewuro' in Yoruba, 'Etidot' in Ibibio, 'Onugbu' in Igbo, 'Ityuna' in Tiv, 'Ilo' in Igala, 'Oriwo' in Edo, 'Chusar-doki' in Hausa. It is the most cultivated and prominent species of the genus Vernonia that is made up of about 1,000 species of shrub [Toyang and Verpoorte, 2013; Egharevba et al., 2014]. The leaves are green in coloration with a characteristic odor and bitter taste [Akpaso et. al., 2011]. There are many accessions based on environmental conditions and features like level of bitterness, size and color of leaves. This herb has been domesticated in many parts of West Africa, but grows freely in tropical Africa and also well distributed in Asia [Oseni and Babatunde, 2016]. It is cultivated in Nigeria mainly for its nutritional value in human diet because of the presence of vitamins and mineral salts which are useful for the maintenance of health, prevention and treatment of various diseases. The leaves of Vernonia amygdalina are used as soup condiments after washing and boiling to get rid of the bitter taste [Hamzah et al., 2013]. Phytochemicals are natural occurring bioactive compounds known for their health benefits. These are produced by the plant's primary and secondary metabolism. They are majorly responsible for the color, flavor and aroma of fruits and notably vegetables. Several studies carried out on Vernonia amygdalina had suggested that it contains different bioactive compounds including; flavonoids, saponins, alkaloids, tannins, phenolics, terpenes, steroidal glycosides, triterpenoids, and several types of sesquiterpene lactones [Quasie et al., 2016; Luo et al., 2017]. These bioactive compounds made them possess different pharmacological properties like antimicrobial, antimalarial, antithrombotic, antioxidant, anti-diabetic, laxative, hypoglycemic, anthelmintic, anti-inflammatory, cathartic, anticancer, antifertility, anti-fungi, antibacterial, and among others [Udochukwu et al., 2015; Alara et al., 2017]. The bitter taste had been associated with the presence of saponins, alkaloids, tannins, and glycosides. The type and quantity of phytochemicals in this plant is affected by the environment. The aim of this project was to run an analysis to ascertain the phytochemicals and nutritional compositions and to determine the relationship between proximate composition and some phytochemicals concentrations of the two bitter leaf accessions.

\section{MATERIALS AND METHODS}

\section{Collection, identification and preparation of plant materials}

Owing to the influence of environmental factors on plants nutritional and phytochemical components, the two accessions of Vernonia amygdalina (bitter leaf) were collected from the same farm under the similar conditions in Rumuodomaya in Obio/Akpor Local government Area, Rivers state. One of the accessions is the conventional upland bitter leaf that is common in the Rainforest zone of Nigeria. It must be washed severally before use. The other one is a Riverine accession 
that is slightly bitter, it can be consumed raw or cooked like any other vegetable and are naturally found in Riverine communities in high rainfall areas of Nigeria. The fresh leaves were identified, separated from the stalk, washed and air-dried at room temperature $\left(24^{\circ} \mathrm{C}\right)$ and then pulverized, crushed into fine powder and weighed at the Food Profiling Biotechnology Laboratory, National Root Crops Research Institute (NRCRI) Umudike, Umuahia, Nigeria. For proximate analysis, the dry matter, moisture, ash, crude fat, crude protein (nitrogen $\mathrm{x}$ 6.25) and crude fibre contents were determined in powdered Vernonia amygdalina leaves using the standard methods of the Association of Official Analytical Chemists [AOAC,2005] while carbohydrate content was calculated based on the net difference between the other nutrients and the total percentage composition.

The Mineral contents in leaves were determined using an atomic absorption spectrophotometer (Buck Scientific Model 205,) using standard protocols (AOAC, 2006). A $0.5 \mathrm{~g}$ amount of crushed composite sample was digested in concentrated nitric acid and perchloric acid at $115^{\circ} \mathrm{C}$ for about $1 \mathrm{~h}$ to generate the digest solution. An aliquot of the digest solution was used for determination of calcium, magnesium, sodium, copper, zinc, iron, and phosphorus contents. High-performance liquid chromatography (HPLC) methods for the determination of water and fat soluble vitamins in foods using the standard methods of the Association of Official Analytical Chemists [AOAC, 2005].

Phytochemical screening was performed using standard procedures [Ayoola et. al,2008]. All the data collected were analyzed using Genstat 12 edition and means were separated using Least significance difference (L.S.D) at 0.05 level of significance.

\section{RESULTS.}

\section{Proximate Analysis on the of Bitter leaf (Vernonia amygdalina) Accessions}

Most of the tested components showed significant difference $(\mathrm{P}<0.05)$ amongst the two accessions on Table1. Riverine accession contained more Ash $(9.45 \mathrm{mg} / 100 \mathrm{~g})$ while Upland accession contained more crude fibre $(4.17 \%)$, fat $(2.44 \%)$, carbohydrate $(40.54 \mathrm{mg} / 100 \mathrm{mg})$ and energy value $(288.42 \mathrm{k} / \mathrm{cal})$. Crude Protein and Moisture content did not significantly vary.

Table1: Proximate Analysis on the of Bitter leaf (Vernonia amygdalina) Accessions

\begin{tabular}{|c|c|c|c|c|c|c|c|}
\hline TREATMENT & $\begin{array}{c}\text { MC } \\
(\%)\end{array}$ & $\begin{array}{c}\text { CP } \\
(\%)\end{array}$ & $\begin{array}{c}\text { CF } \\
(\%)\end{array}$ & $\begin{array}{c}\text { FAT } \\
(\%)\end{array}$ & $\begin{array}{c}\text { ASH } \\
\mathrm{Mg} / 100 \mathrm{~g}\end{array}$ & $\begin{array}{c}\text { CHO } \\
\mathrm{Mg} / 100 \mathrm{~g}\end{array}$ & $\begin{array}{c}\text { EV } \\
\mathrm{K} / \mathrm{cal}\end{array}$ \\
\hline UPLAND & 18.47 & 26.09 & 4.17 & 2.44 & 8.31 & 40.54 & 288.42 \\
\hline RIVERINE & 20.06 & 29.47 & 3.06 & 2.08 & 9.45 & 35.95 & 280.31 \\
\hline LSD $_{0.05}$ & 0.09 & 0.05 & 0.03 & 0.03 & 0.04 & 0.04 & 0.13 \\
\hline
\end{tabular}

MC-Moisture Content, CP- Crude Protein, CF- Crude Fibre, CHO- Carbohydrate, EV-Energy Value.

Minerals composition analysis of the two accessions of bitter leaf (V. amygdalina)

Table. 2 showed some significant differences amongst the two accessions of bitter leaf minerals content. The Riverine accession contained more of the tested minerals except Calcium, while Magnesium and Potassium were not significantly different.

Table 2: Minerals composition analysis of the two accessions of bitter leaf ( $V$. amygdalina)

\begin{tabular}{|c|c|c|c|c|c|c|c|}
\hline TRT & $\begin{array}{c}\mathrm{CA} \\
\mathrm{Mg} / 1 \\
00 \mathrm{~g}\end{array}$ & $\begin{array}{c}\mathrm{NA} / 1 \\
\mathrm{Mg} / 1\end{array}$ & $\begin{array}{c}\mathrm{MG} / 1 \\
\mathrm{Mg} / 1\end{array}$ & $\begin{array}{c}\mathrm{Pg} / 1 \\
00 \mathrm{~g}\end{array}$ & $\begin{array}{c}\mathrm{K} \\
\mathrm{Mg} / 1 \\
00 \mathrm{~g}\end{array}$ & $\begin{array}{c}\mathrm{FE} \\
\mathrm{Mg} / 1 \\
00 \mathrm{~g}\end{array}$ & $\begin{array}{c}\mathrm{ZN} \\
\mathrm{Mg} / 1 \\
00 \mathrm{~g}\end{array}$ \\
\hline $\begin{array}{c}\text { UPLAN } \\
\mathrm{D}\end{array}$ & 73.25 & $\begin{array}{c}134.0 \\
6\end{array}$ & $\begin{array}{c}141.3 \\
7\end{array}$ & 6.93 & $\begin{array}{c}902.2 \\
5\end{array}$ & 0.82 & 0.23 \\
\hline $\begin{array}{c}\text { RIVERI } \\
\mathrm{NE}\end{array}$ & 70.51 & $\begin{array}{c}180.3 \\
6\end{array}$ & $\begin{array}{c}162.5 \\
4\end{array}$ & 27.87 & $\begin{array}{c}949.3 \\
5\end{array}$ & 1.13 & 0.48 \\
\hline $\mathrm{LSD}_{0.05}$ & 0.029 & 0.03 & 0.05 & 0.04 & 0.08 & 0.03 & 0.03 \\
\hline
\end{tabular}

CA: Calcium, NA: Sodium, MG: Magnesium, P: Phosphorus, K: Potassium, FE: Iron, ZN: Zinc

Vitamins composition analysis on two accessions of bitter leaf (V. amygdalina)

The results showed that Riverine accession contained more Vitamin B1 $(0.16 \mathrm{mg} / 100 \mathrm{~g})$ and Vitamin
$\mathrm{E}(0.32 \mathrm{mg} / 100 \mathrm{~g})$. While the upland accession contained more of VitaminB2 $(0.22 \mathrm{mg} / 100 \mathrm{~g})$ and VitaminB3 $(0.15 \mathrm{mg} / 100 \mathrm{mg})$. Vitamins $\mathrm{A}$ and $\mathrm{C}$ did not vary significantly. Table 3.

Table3: Vitamins composition analysis on two accessions of bitter leaf ( $V$. amygdalina)

\begin{tabular}{|c|c|c|c|c|c|c|}
\hline $\begin{array}{c}\text { TREATME } \\
\text { NT }\end{array}$ & $\begin{array}{c}\text { VIT A } \\
\mathrm{Mg} / 10 \\
0 \mathrm{~g}\end{array}$ & $\begin{array}{c}\text { VIT } \\
\mathrm{B} 1 \\
\mathrm{Mg} / 10 \\
0 \mathrm{~g}\end{array}$ & $\begin{array}{c}\text { VIT } \\
\mathrm{B} 2 \\
\mathrm{Mg} / 10 \\
0 \mathrm{~g}\end{array}$ & $\begin{array}{c}\text { VIT } \\
\mathrm{Bg} 3 \\
0 \mathrm{~g}\end{array}$ & $\begin{array}{c}\mathrm{VIT} \mathrm{C} \\
\mathrm{Mg} / 10 \\
0 \mathrm{~g}\end{array}$ & $\begin{array}{c}\mathrm{VIT} \mathrm{E} \\
\mathrm{Mg} / 10 \\
0 \mathrm{~g}\end{array}$ \\
\hline UPLAND & 0.11 & 0.15 & 0.22 & 0.15 & 6.43 & 0.12 \\
\hline RIVERINE & 0.29 & 0.16 & 0.19 & 0.14 & 8.54 & 0.32 \\
\hline LSD $_{0.05}$ & 0.16 & 0.03 & 0.02 & 0.03 & 0.05 & 0.03 \\
\hline
\end{tabular}

VIT(Vitamin);VIT A(Vitamin A) VIT B1(Thiamin), VIT B2(Riboflavin),VIT B3(Niacin), VIT C(Ascorbic acid),VIT E(Tocopherol)

Phytochemical analysis on the two accessions of bitter leaf (Vernonia amygdalina)

Table 4 showed that Upland accession contained more Tannins $(0.75 \%)$, Phytate $(124.13 \mathrm{mg} / 100 \mathrm{~g})$, Steriods $(0.002 \%)$ and Oxalate $(1.48 \mathrm{mg} / 100 \mathrm{~g})$, Cyanogenic glycosides $(44.77 \mathrm{mg} / 100 \mathrm{~g})$, Anthraquinone $(0.06 \%)$ than Riverine Upland accession which contained more Saponin 
$(0.21 \%)$. Total phenols ,Flavoniods and Alkaloids were not significantly different.

Table4: Phytochemical analysis on the two accessions of bitter leaf (Vernonia amygdalina)

\begin{tabular}{|c|c|c|c|c|c|c|c|c|c|c|}
\hline TREATMENT & $\begin{array}{c}\text { FLA } \\
\%\end{array}$ & $\begin{array}{c}\text { ALK } \\
\%\end{array}$ & $\begin{array}{c}\text { SAP } \\
\%\end{array}$ & $\begin{array}{c}\text { TAN } \\
\%\end{array}$ & $\begin{array}{c}\text { PHE } \\
\mathrm{Mg} / 100 \mathrm{~g}\end{array}$ & $\begin{array}{c}\text { OXA } \\
\mathrm{Mg} / 100 \mathrm{~g}\end{array}$ & $\begin{array}{c}\text { PHY } \\
\mathrm{Mg} / 100 \mathrm{~g}\end{array}$ & $\begin{array}{c}\text { C.GLY } \\
\mathrm{Mg} / 100 \mathrm{~g}\end{array}$ & $\begin{array}{c}\text { STE } \\
\%\end{array}$ & $\begin{array}{c}\text { ANT } \\
\%\end{array}$ \\
\hline RIVERINE & 3.13 & 1.17 & 0.21 & 0.41 & 2.16 & 0.86 & 103.87 & 37.10 & 0.001 & 0.07 \\
\hline $\mathrm{LSD}_{0.05}$ & 0.05 & 0.07 & 0.03 & 0.02 & 0.05 & 0.04 & 0.03 & 0.12 & 0.002 & 0.01 \\
\hline
\end{tabular}

FLA=Flavonoids, ALK=Alkaloids, SAP=Saponin, TAN=Tannins, PHE=Phenol, PHY=Phytate, OXA=Oxalate, C.GLY=Cyanogenic glycosides, ANT=Anthraquinone, $\mathrm{STE}=$ Steroids.

Proximate and phytochemical components correlation.

Correlation analysis between phytochemical and proximate components showed (Table 5) that the phytochemical components correlated positively at 0.01 level of significance among themselves and with the proximate components except for saponin, anthraquinone and steroids.

\section{DISCUSSION}

The Proximate compositions of the two accessions of $V$. amygdalina leaves varied. The Riverine bitter leaf contained more moisture content $(20.06 \%)$, crude protein $(29.47 \%)$ and ash $(9.45 \mathrm{mg} / 100 \mathrm{~g})$ while Upland accession had more crude fibre $(4.17 \%)$, fat $(2.44 \%)$, carbohydrate $(40.54 \%)$ and energy value $(288 \mathrm{kcal}$.$) . The proximate values were in line with the$ findings of IIondu,(2010). Their crude protein content is higher than Amaranthus caudatus (20.5\% DW), but lower than Piper guineeses $(29.78 \% \mathrm{DW})$ and $T$. triangulare (31.00\% DW)(IIondu,2010). Since food that provide more than $12 \%$ of their caloric value from proteins are very good sources of protein, the two accessions can be classified as very rich in proteins and can serve as substitutes for protein, especially among rural dwellers. Proteins are building block units and the food protein is needed to make vital hormones, important brain chemicals, antibodies, digestive enzymes, and necessary elements for the manufacture of DNA. Some proteins are involved in structural support, while others are involved in bodily movement, or in defense against germs. So, the riverine accession is richer in protein related components while the upland accession is richer in energy related components. The Riverine bitter leaf contains more minerals; sodium $(180.36 \mathrm{mg} / 100 \mathrm{~g})$, magnesium $(162.54 \mathrm{mg} / 100 \mathrm{~g})$, phosphorus $(27.87 \mathrm{mg} / 100 \mathrm{~g})$, potassium $(949.35 \mathrm{mg} / 100 \mathrm{mg})$, iron $(1.13 \mathrm{mg} / 100 \mathrm{~g})$ and zinc $(0.48 \mathrm{mg} / 100 \mathrm{~g})$. This makes it a very good source of minerals especially as it can be taken raw. V.amygdalina is rich in zinc (George will and George will,2010).Zinc is an essential micronutrient for human health since it cannot be produced or stored in excess in the body. In spite of the proven benefits of adequate zinc nutrition, approximately 2 billion people still remain at risk of zinc deficiency. Zinc is found as component of more than 300 enzymes and hormones and plays a crucial part in the health of our skin, teeth, bones, hair, nails, muscles, nerves and brain function as well as it is essential for growth.
Zinc deficiency is an important public health problem, affecting large number of women and children in developing countries worldwide. Zinc deficiency is the fifth leading risk factor for disease in the developing world (Devi et. al., 2014). The upland accession is richer only in calcium .The presence of more ash in riverine bitter leaf is a confirmation of the presence of more mineral elements. This result affirms reports of Ezekiel et al.,(2015) that observed minerals content in Vernonia amygdalina in the trend; $\mathrm{K}>\mathrm{Na}$ $>\mathrm{Ca}>\mathrm{Mg}>\mathrm{Fe}>\mathrm{Zn}>\mathrm{Cu}>\mathrm{Mn}$. Potassium was the predominant mineral element detected while manganese was the least detected minerals element. Inorganic mineral elements such as potassium and calcium are known to play important roles in the maintenance of normal glucosetolerance and in the release of insulin from beta cells of islets of Langerhans which helps to control the glucose level of the human body (Kadiri, 2015).

V. amygdalina is rich in Vitamin $\mathrm{A}$, Vitamin $\mathrm{C}$, Vitamin E, Vitamin $\mathrm{B}_{1}$, and Vitamin $\mathrm{B}_{2}$ and hence, is effective in the treatment of a variety of common ailments as postulated by (Adenuga et. al.,2010). The Riverine bitter leaf contains more vitamin $\mathrm{B}_{1}(0.16 \mathrm{mg} / 100 \mathrm{~g})$ and vitamin $\mathrm{E}$ $(0.32 \mathrm{mg} / 100 \mathrm{~g})$. Vitamin C (ascorbic acid) supports cellular membrane integrity (Kumari et. al., 2017). Although not significantly different both accessions contain comparatively high Vitamins $\mathrm{A}$ and $\mathrm{C}$ which can avert formation of cancercausing N-nitrous compounds (Kaur and Kapoor, 2001). The high content of Ascorbic acid of $V$. amygdalina indicates the leaves might be a source of vitamin C. Although there are variations in bitter leaf vitamins composition, this finding is in line with that of (Nwaoguikpe, 2010) that bitter leaf is rich in Vitamin A, C and E. The Upland bitter leaf contains higher concentrations of the tested phytochemicals except saponin $(0.21 \%)$ and this is in accord with Udochukwu et. al., (2015) report. Also, in a study conducted by Usunobun and Ngozi (2016) found that saponins, tannins, alkaloids and flavonoids, triterpenoids, steroids and cardiac glycosides were high in $V$. amygdalina which served as a great source of pharmacologically active phytochemicals and effective as supplements in human and animal nutrition.

Correlation analysis between phytochemical and proximate components showed that the phytochemical components correlated positively at 0.01 level of significance 
among themselves and with the proximate components except for saponin, anthraquinone and steroids.

\section{Conflict of Interest}

The authors report no conflict of interest.

\section{REFERENCES}

[1] Adenuga, W., O.N. Olaleye, and P.A. Adepoju. (2010). Utilization of bitter vegetable leaves (Gongronema latifolium, Vernonia amygdalina) and Garcinia kola extracts as substitutes for hops in sorghum beer production. Afr. J. Biotechnol. 9:8819-8823.

[2] Akpaso, M. I., Atangwho, I. J., Akpantah, A., Fischer, V.A., Igiri, A. O. and Ebong, P. E. 2011. Effect of Combined Leaf Extracts of Vernonia amygdalina (Bitter Leaf) and Gongronema latifolium (Utazi) on the Pancreatic $\beta$-Cells of Streptozotocin-Induced Diabetic Rats. British Journal of Medicine \& Medical Research. 1(11):24-34.

[3] Alara, O.R., Nour, A., Adbul-mudalip, S.K., and Olalere, O. A. (2017). Phytochemical and pharmacological properties of Vernonia amygdalina-A REVIEW. J Chem. Eng. \& Industrial Biotechnol 2:80-96. https://doi: 10.15282/JCEIBV207.29/9/2017/2.2

[4] AOAC (2005), Official methods of analysis. 18th ed. Association of Official Agricultural Chemists, Washington DC.

[5] .AOAC (2006). Official methods of analysis. 18th ed. Association of Official Agricultural Chemists, Gaithersburg, MD.

[6] Ayoola, G. A., Coker, H. A., Adesegun, S. A., Adepoju-Bello, A. A., Obaweya, K., Ezennia, E. C., \& Atangbayila, T. O. (2008). Phytochemical screening and antioxidant activities of some selected medicinal plants used for malaria therapy in Southwestern Nigeria. Tropical Journal of Pharmaceutical Research, 7(3), 1019 1024.

[7] Devi, Ch.Bimola,Th. Nandakishore,Sangeeta N,Gomi Basar,N.Omita Devi,Sungdirenla Jamir and M.Amuba Singh(2014):Zinc in Human health.IOSR Journal of Dental and Medical Sciences (IOSR-JDMS) e-ISSN: 2279-0853, p-ISSN: 2279-0861.Volume 13, Issue 7 Ver. II (July. 2014), PP 18-23 www.iosrjournals.org

[8] Egharevba, C., Osaymwenre, E., Imieje, V., Ahomafor, J., Akunyili, C., Udu-Cosi, A. A. Onyekaba,T .J. Osakue, J. A., Iftikhar, A., and Falodun, A. (2014) Significance of Bitter Leaf (Vernonia amygdalina) In Tropical Diseases and Beyond: A Review. Mal Chem. Control \& Elimination.3 120. https://doi:10.4172/2090-2778.1000120.

[9] Ezekiel A, Ojo AA, Ogunmodede OT, Adewumi DF. 2015. Antioxidant Activities and Nutritional Composition of Vernonia amygdalina. Int. J of Basic Appl. Sci., 4(1): 9-16.

[10] George will, OA. and George will, U. O. 2010. Evaluation of the Anti-inflammatory Activity of Extract of Vernonia amygdalina. Asian Pacific Journal of Tropical Medicine.150-151.DOI: 10.1016/S1995-7645(10)60057-0

[11] Hamzah, R.U., Jigam, A.A., Makun, H.A. and Egwin, E.C. (2013). Antioxidant Properties of Selected African Vegetables, Fruits and
Mushrooms: A Review. Intech, 9, 203-250. https:// doi.org/10.5772/52771.

[12] Ilondu, E. M. (2013). Phytochemical composition and efficacy of ethanolic leaf extracts of some Vernonia species against two phytopathogenic fungi. Journal of Bio pesticides, 6(2), 165.

[13] Kadiri O. 2015. Studies on the Chemical Composition, Functional and Antioxidant Properties of Carica Papaya (Pawpaw) Seed flour, Protein concentrate and Protein isolate, Protein concentrate and Protein isolate. M.sc thesis Department of Food Science and Technology, Obafemi Awolowo University, Ile-Ife, Nigeria, pp.75-78

[14] Kambizi, L. and Afolayan, A.J. (2001). An ethnobotanical study of plants used for the treatment of sexually transmitted diseases (njovhera) in Guruve District, Zimbabwe. Journal of Ethno pharmacology, 77(1), 5-9. https:// doi.org/10.1016/S0378-8741 (01)00251-3

[15] Kaur, C., and H.C. Kapoor. (2001). Antioxidants in fruits and vegetables - the millennium's health. Int. J. Food Sci. Technol. 36:703-725. Doi: 10.1046/j.1365-2621.2001.00513.x

[16] Kumari, A., A.K. Parida, J. Rangani, and A. Panda. (2017). Antioxidant activities, metabolic profiling, proximate analysis, mineral nutrient composition of Salvador apersica fruit; Unravel a potential functional food and a natural source of pharmaceuticals. Front Pharmacol. 8:61 (abs). Doi: 10.3389/fphar.2017.00061

[17] Liu, W., Yin, D., Li, N., Hou, X., Wang, D., Li, D., \& Liu, J. (2017). Influence of environmental factors on the active substance production and antioxidant activity in Potentilla fruticosa L. and its quality assessment. Scientific reports, 6(1), 1-18.

[18] Nwaoguikpe, R.N. (2010). The effect of extract of bitter leaf (Vernonia amygdalina) on blood glucose levels of diabetic rats. International Journal of Biology and Chemical Sciences, 4(3), 729-729. https://doi.org/10.4314/ijbcs.v4i3.60500

[19] Oseni, K. and Babatunde, O. (2016). Vernonia amygdalina: An Underutilized Vegetables with Nutraceutical Potentials - A Review. Turkish Journal of Agriculture - Food Science and Technology, 463-768. https://doi.org/10.24925/turjaf.v4i9.763- 768.570

[20] Quasie, O., Zhang, Y., Zhang, H., Luo, J. and Kong, L. (2016). Four new steroid saponins with highly oxidized side chains from the leaves of Vernonia amygdalina. Journal of Photochemistry Letters, 15, 16-20. https://doi.org/10.1016/j.phytol.2015.11.002

[21] Toyang, N. J. and Verpoorte, R. (2013). A Review of the Medicinal Potentials of Plants of the Genus Vernonia (Asteraceae). Journal of Ethno pharmacology. 146(3): 681-723.

[22] Udochukwu, U., Omeje, F.I., Uloma, I.S., Oseiwe, F.D. (2015). Phytochemical analysis of Vernonia amygdalina and Ocimum gratissimum extracts and their antibacterial activity on some drug resistant bacteria. American Journal of Research Communication, $3(5), 225-235$.

[23] Usunobun, U. and Ngozi, O. (2016). Phytochemical analysis and proximate composition of Vernonia amygdalina. International Journal of Scientific World, 4(1), 11. https://doi.org/10.14419/ ijsw.v4i1.5845 
International Journal of Research and Innovation in Applied Science (IJRIAS) |Volume VI, Issue XII, December 2021||ISSN 2454-6194

Table 5.Proximate and phytochemical components correlation

\begin{tabular}{|c|c|c|c|c|c|c|c|c|c|c|c|c|c|c|c|c|c|}
\hline & FLA & ALK & SAP & TAN & PHE & PHY & OXA & $\begin{array}{l}\text { C.GL } \\
\text { Y }\end{array}$ & ANT & STE & MC & $\mathrm{CP}$ & $\mathrm{CF}$ & FAT & ASH & $\mathrm{CHO}$ & $\begin{array}{l}E \\
V\end{array}$ \\
\hline FLA & 1 & & & & & & & & & & & & & & & & \\
\hline ALK & $\underset{x}{0.999^{x}}$ & 1 & & & & & & & & & & & & & & & \\
\hline SAP & -0.746 & 0.726 & 1 & & & & & & & & & & & & & & \\
\hline TAN & $\underset{x}{0.999^{x}}$ & $\underset{x}{0.999^{x}}$ & -0735 & 1 & & & & & & & & & & & & & \\
\hline PHE & $\underset{x}{1.000^{x}}$ & $\underset{x}{1.000^{x}}$ & -0.730 & $\underset{x}{0.999^{x}}$ & 1 & & & & & & & & & & & & \\
\hline PHY & $\underset{x}{1.000^{x}}$ & $\underset{x}{1.000^{x}}$ & -0.741 & $\underset{x}{0.999^{x}}$ & $\underset{x}{1.000^{x}}$ & 1 & & & & & & & & & & & \\
\hline OXA & $\underset{x}{0.999^{x}}$ & $\underset{x}{1.000^{x}}$ & -0.716 & $\underset{x}{0.998^{x}}$ & ${ }_{\mathrm{x}}^{1.000^{\mathrm{x}}}$ & $\underset{x}{0.999^{x}}$ & 1 & & & & & & & & & & \\
\hline $\begin{array}{c}\text { C.GL } \\
\mathrm{Y}\end{array}$ & $\underset{x}{1.000^{x}}$ & $\underset{x}{1.000^{x}}$ & -0.739 & $\underset{x}{0.999^{x}}$ & $\underset{x}{1.000^{x}}$ & $\underset{x}{1.000^{x}}$ & $\underset{x}{0.999^{x}}$ & 1 & & & & & & & & & \\
\hline ANT & -0.720 & -0.739 & -0.283 & -0.727 & -0.733 & -0.728 & -0.753 & 1 & & & & & & & & & \\
\hline STE & 0.454 & 0.447 & -0.332 & 0.434 & 0.447 & 0.447 & 0.454 & 0.449 & -0.434 & 1 & & & & & & & \\
\hline $\mathrm{MC}$ & $\underset{x}{0.999^{x}}$ & $\underset{x}{0.998^{x}}$ & 0.763 & $\underset{x}{0.997^{x}}$ & $\underset{x}{0.998^{x}}$ & $\underset{x}{0.999^{x}}$ & $\underset{x}{0.997^{x}}$ & $\underset{x}{0.999^{x}}$ & 0.727 & -0.457 & 1 & & & & & & \\
\hline $\mathrm{CP}$ & $\underset{\mathrm{x}}{-}$ & $\underset{\mathrm{x}}{-}$ & 0.740 & $\underset{x}{0.999^{x}}$ & $\underset{x}{-}$ & -1.100 & $\begin{array}{c}- \\
0.999^{\mathrm{x}} \\
\mathrm{x}\end{array}$ & $\underset{\mathrm{x}}{-}+0^{\mathrm{x}}$ & 0.733 & -0.444 & $0.999^{\mathrm{xx}}$ & 1 & & & & & \\
\hline $\mathrm{CF}$ & $\frac{1.000^{x}}{x}$ & $\underset{x}{0.999^{x}}$ & -0.749 & $\underset{x}{0.999^{x}}$ & $\underset{x}{1.000^{x}}$ & $\underset{\mathrm{x}}{1.000^{\mathrm{x}}}$ & $\underset{x}{0.998^{x}}$ & $\underset{\mathrm{x}}{1.000^{\mathrm{x}}}$ & -0.717 & 0.452 & $0 . \overline{9} 9^{\mathrm{xx}}$ & $\underset{x}{-}$ & 1 & & & & \\
\hline FAT & $\underset{x}{0.998^{x}}$ & $\underset{x}{0.999^{x}}$ & -0.717 & $\underset{x}{0.999^{x}}$ & $\underset{x}{0.999^{x}}$ & $\underset{x}{0.998^{x}}$ & $\underset{x}{0.998^{x}}$ & $\underset{x}{0.999^{x}}$ & -0.717 & 0.442 & $0.995^{\mathrm{xx}}$ & $\underset{x}{0.998^{x}}$ & $0.998^{\mathrm{xx}}$ & 1 & & & \\
\hline ASH & $\underset{x}{0.999^{x}}$ & $\begin{array}{c}- \\
0.999^{x}\end{array}$ & 0.742 & $\underset{x}{-}+997^{x}$ & $\underset{x}{0.999^{x}}$ & $\underset{\mathrm{x}}{-}$ & $\begin{array}{c}- \\
0.999^{x}\end{array}$ & $\underset{x}{0.999^{x}}$ & -0.733 & -0.442 & $0.999^{x x}$ & $\underset{x}{1.000^{x}}$ & $0.999^{-}$ & $\underset{\mathrm{xx}}{0 .} \overline{-}$ & 1 & & \\
\hline $\mathrm{CHO}$ & $\underset{x}{1.000^{x}}$ & $\underset{x}{1.000^{x}}$ & -0.744 & $\underset{x}{0.999^{x}}$ & $\underset{\mathrm{x}}{1.000^{\mathrm{x}}}$ & $\underset{\mathrm{x}}{1.000^{\mathrm{x}}}$ & $\underset{x}{0.999^{x}}$ & $\frac{1.000^{x}}{x}$ & -0.725 & 0.446 & $0 . \overline{-}$ & $\underset{x}{-}$ & $1.000^{\mathrm{xx}}$ & $\underset{\mathrm{xx}}{0.998}$ & $\underset{\mathrm{x}}{-}$ & 1 & \\
\hline EV & $\frac{1.000^{x}}{x}$ & $\underset{x}{0.999^{x}}$ & -0.745 & $\underset{x}{0.998^{x}}$ & ${ }_{\mathrm{x}}^{1.000^{\mathrm{x}}}$ & $\underset{\mathrm{x}}{1.000^{\mathrm{x}}}$ & $\underset{x}{0.999^{x}}$ & $\underset{x}{1.000^{x}}$ & -0.722 & 0.448 & $0.999^{\mathrm{xx}}$ & $\underset{\mathrm{x}}{-}$ & $1.000^{\mathrm{xx}}$ & $\underset{\mathrm{xx}}{0.998}$ & $\underset{\mathrm{x}}{-}$ & $1.000^{\mathrm{xx}}$ & 1 \\
\hline
\end{tabular}

${ }^{x x}$ correlation positive at 0.01 level of significance, ${ }^{x}$ correlation positive at 0.01 level of significance,

FLA=Flavonoids, ALK=Alkaloids, SAP=Saponin, TAN=Tannins, PHE=Phenol, PHY=Phytate, OXA=Oxalate, C.GLY=Cyanogenic glycosides, ANT=Anthraquinone, STE=Steroids.MC-Moisture Content, CP- Crude Protein, CF- Crude Fibre, CHO- Carbohydrate, EV-Energy Value. 